\title{
PENINGKATAN HASIL BELAJAR BAHASA INGGRIS MELALUI METODE BERNYANYI PADA SISWA KELAS IA MI NURUL ANWAR KOTA BEKASI
}

\author{
Suryani Kartika \\ M.Samsul Khaeri
}

Sekolah Tinggi Agama Islam Bani Saleh

JIn. M. Hasibuan No.68 (Lantai 2) Bekasi Timur 17113

suryanikartika93@gmail.com, samsul_khaeri@yahoo.com

Naskah masuk: 16-05-20, direvisi: 21-05-20, diterima: 16-05-20, dipublikasi: 30-04-20

\begin{abstract}
Abstrak: Penelitian ini dilakukan di MI Nurul Anwar Kota Bekasi. Metode yang digunakan pada penelitian ini adalah metode penelitian tindakan kelas (PTK) dengan menggunakan metode bernyanyi. Jumlah siswa yang diteliti yaitu 36 siswa dengan 21 siswa perempuan dan 15 siswa laki-laki. Penelitian ini dilatar belakangi oleh permasalahan rendahnya hasil belajar kosakata bahasa inggris pada siswa kelas IA MI Nurul Anwar Kota Bekasi. Dikarenakan siswa masih kesulitan dalam hal mendengarkan, membaca, menulis, berbicara kosakata bahasa inggris oleh karena itu peneliti berupaya meningkatkan hasil belajar kosa kata bahasa inggris melalui metode bernyanyi yang disenangi siswa dan membuat siswa lebih aktif dalam proses pembelajaran bahasa inggris. Penelitian dilaksanakan dalam dua siklus. Setiap siklus dilaksanakan empat kali tindakan penelitian. Dengan kriteria ketuntasan $\geq 75 \%$. Hasil yang diperoleh pada prapenelitian $33,97 \%$, siklus I $58,22 \%$, siklus II $78,38 \%$. Dengan demikian ini maka dikatakan telah berhasil pada siklus ke II. Dengan demikian penelitian ini dapat dinyatakan bahwa melalui metode bernyanyi dapat meningkatkan hasil belajar bahasa inggris pada siswa kelas IA MI Nurul Anwar Kota Bekasi.
\end{abstract}

Kata kunci: Metode Bernyanyi, Hasil Belajar, Kosakata, Bahasa Inggris.

\begin{abstract}
This research was conducted in the town of Bekasi Nurul Anwar MI. The methods used in this research is the research methods class action (PTK) using a method of singing. The number of students who researched i.e. 36 students with 21 students are female and 15 male students. This event will be based on researchers by the low level of the results of learning English vocabulary in grade IA MI Nurul Anwar Bekasi. Because the students are still difficulties in terms of listening, reading, writing, speaking English vocabulary is therefore researchers working to improve the results of learning English vocabulary through a singing endeared methods students and make students more actively in the process of learning English. The research was conducted in two cycles. Each cycle is conducted four times the action research. Criteria ketuntasan $\geq 75 \%$. The results obtained on prapenelitian $33.97 \%$, cycle I $58.22 \%$, cycle II $78.38 \%$. Thus this then is said to have succeeded on cycle II.Thus this research it can be stated that through the singing methods can improve the results of learning English at grade IA MI Nurul Anwar Bekasi..
\end{abstract}

Keywords: Singing Method, Results of study, vocabulary, English language..

\section{PENDAHULUAN}

Bahasa Inggris merupakan suatu bahasa yang sangat penting dalam dunia internasional khususnya di era globalisasi sekarang ini. Bahasa Inggris memegang kunci sebagai bahasa internasional. Ahmad
(2016:9) berpendapat bahwa bahasa Inggris merupakan alat komunikasi antar orangorang di dunia untuk perdagangan, sosialbudaya, ilmu pengetahuan dan tujuan lainya. Dengan Bahasa Inggris orang juga 
dapat dengan mudah mengakses sebagai informasi dan teknologi (Bussim, 2016:9). Peranan bahasa Inggris jika dikaji lebih jauh bisa sebagai penghubung antar Negara. Apalagi saat ini Indonesia merupakan negara yang berkembang di bidang industri, selain itu Indonesia pun akan mulai memasuki pasar bebas. Oleh karena itu, Bahasa Inggris sangat diperlukan oleh masyarakat Indonesia sebagai penunjang komunikasi dengan orang asing yang ada di Indonesia.

Menyadari kenyataan pentingnya bahasa Inggris di masa depan, maka pembelajaran Bahasa Inggris sedini mungkin harus diterapkan di sekolahsekolah yang merupakan salah satu upaya peningkatan kompetensi individu dalam pembelajaran Bahasa Inggris. Mengingat ke depan persaingan yang dihadapi dengan bangsa lain maka tamatan suatu sekolah selain harus mempunyai kompetensi produktif juga harus mempunyai kompetensi bahasa inggris, karena bahasa inggris merupakan bahasa pengantar yang dipakai secara internasional. Kenyataanya yang ada di dunia kerja, yaitu usaha dan dunia industri, bahwa penggunaan bahasa Inggris bagi tenaga kerja bukan hanya untuk memahami petunjuk, membaca manual ataupun memahami instruksi penggunaan peralatan lainnya, namun lebih pada penggunaan untuk berkomunikasi lisan, dan untuk bisa berkomunikasi secara baik harus menguasai kosakata yang memadai pula. Hal ini didukung dengan firman Allah SWT, yaitu :

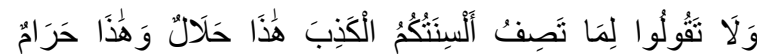

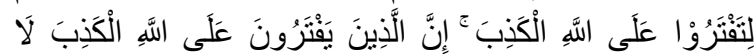
يُنْلِحُونَ (116)

"Dan janganlah kamu mengatakan terhadap apa yang disebut-sebut oleh lidahmu secara dusta "ini halal dan ini haram", untuk mengada-adakan

kebohongan terhadap Allah.
Sesungguhnya orang-orang yang
mengada-adakan kebohongan
terhadap Allah tiadalah beruntung."
(QS. AN Nahl : 116)
Agama (2000: 419$)$

Pada umumnya komponen bahasa Inggris terdiri dari tiga komponen yaitu grammar (tata bahasa), Vocabulary (kosakata), dan pronounciation (pelafalan). Salah satu target pembelajaran bahasa Inggris yang mutlak diperlukan adalah dalam hal penguasaan Kosakata. Dalam hal ini target yang harus dicapai oleh peserta didik yaitu peningkatan kosakata sesuai target capaian sekolah dan pemahaman makna dari kosakata tersebut. Diharapkan setelah lulus dari sekolah dasar, siswa sudah mempunyai kemampuan pengucapan kosakata yang memadai dan mampu memahami bacaan yang sederhana maupun melafalkan dialog seharihari.Kosakata merupakan kata-kata yang dipahami orang baik maknanya maupun penggunaanya.

Penguasaan kosakata merupakan hal terpenting yang harus dikuasai oleh siswa dalam pembelajaran bahasa Inggris, Karena pembelajaran bahasa Inggris tidak mungkin siswa untuk membaca, menulis, dan berbicara bahasa Inggris atau bahasa asing tanpa mempunyai pengetahuan kosakata yang cukup. Mempelajari kosakata baru tidak hanya mengingat bentuk kata tetapi juga mengerti arti dari kosakata baru tersebut.

Berdasarkan hasil observasi awal terhadap nilai pelajaran Bahasa Inggris di MI Nurul Anwar Kota Bekasi khususnya kelas IA masih sangat rendah. Ditemukan bahwa masih terdapat sekitar $50 \%$ dari 35 siswa yang belum mencapai Kriteria Ketuntasan Minimum (KKM). Adapun nilai KKM untuk pelajaran Bahasa Inggris kelas 
IA MI Nurul Anwar Kota Bekasi yaitu 7,5. (wawancara guru kelas I)

Selain itu peserta didik merasa kesulitan dalam menerima mata pelajaran bahasa Inggris. Hal ini dikarenakan pelajaran bahasa Inggris bukan bahasa Ibu melainkan bahasa asing dan sulit dimengerti siswa. Siswa merasa malas dan sulit dalam menghafal kosakata-kosakata bahasa Inggris, karena dalam menghafal tersebut peserta didik merasa terbebani dalam penggunaan dua bahasa sekaligus yaitu bahasa Inggris dan menerjemahkan ke dalam bahasa Indonesia.

Pada sisi lain, faktor guru juga mempengaruhi peserta didik dalam pencapaian penguasaan Kosakata siswa. Dalam penyampaian materi tidak sedikit guru yang memberikannya secara menonton tanpa adanya variasi yang membuat siswa tertarik dan antusias mengikuti pelajaran. Metode ceramah menjadi metode yang sering digunakan guru dalam proses pembelajaran tanpa adanya penyajian pembelajaran yang kreatif, menarik dan membekas dalam pikiran siswa. Sehingga pembelajaran menjadi membosankan dan tidak menarik.

Salah satu upaya yang dilakukan guru dalam meningkatkan hasil belajar kosakata bahasa Inggrisyaitu menggunakan metode bernyanyi. Agar siswa tertarik dan berminat mengikuti mata pelajaran bahasa Inggris, Membuat siswa senang akan pelajaran bahasa Inggris. Menjadikan proses pembelajaran menjadi efektif dan menyenangkan untuk siswa. Mengajarkan peserta didik agar lebih semangat dan aktif dalam proses pembelajaran sehingga dapat meningkatkan hasil belajar siswa.

Salah satu metode yang dapat digunakan untuk meningkatkan hasil belajar Bahasa Inggris adalah metode bernyanyi. Bernyanyi merupakan salah satu metode pembelajaran yang efektif untuk anak-anak.
Nurhid (2016:9) Metode ini telah dimanfaatkan sekali oleh dunia pendidikan terutama pendidikan anak-anak. Bernyanyi bagi anak dapat berperan sebagai wahana yang dapat mengungkapkan pikiran dan perasaan. Maka dari itu peneliti tertarik untuk menerapkan pembelajaran dengan menggunakan metode bernyanyi dalam proses pembelajaran pada pelajaran bahasa Inggris khususnya dalam peningkatan hasil belajar kosakata bahasa Inggris.

Berbicara tentang hasil belajar Bahasa Inggris. Sangatlah penting diajarkan kepada siswa. Hal ini sejalan dengan kurikulum bahasa Inggris kelas I semester satu terdapat Standar Kompetensi (SK) yaitu memahami instruksi, mengungkapkan informasi, memahami tulisan bahasa Inggris, serta mengeja dan menyalin tulisan bahasa Inggris sangat sederhana dalam konteks kelas. Dan Adapun Kompetensi Dasar (KD) yaitu merespon dengan mengulang apa yang di ucapkan guru, tanya jawab yang berkaiatan dengan kosakata, membaca kosakata bahasa Inggris materi alat-alat tulis dengan pelafalan bahasa Inggris yang tepat, membaca teks deskriptif sangat sederhana berbentuk cerita yang singkat, menyalin mencocokan kosakata dengan gambar, serta menulis nama-nama alat tulis dengan tepat. Kompetensi tersebut didukung dengan beberapa indikator yaitu meliputi, siswa dapat menunjukkan beberapa gambar yang diminta oleh guru dan menirukan kembali bunyi suara tersebu, siswa dapat mengungkapkan berbagai tindakan tutur yaitu menanyakan suatu benda sesuai kosakata, siswa dapat mengidentifikasi berbagai kosakata dalam teks deskriptif, siswa dapat menentukan kata yang sesuai dengan gambar, siswa dapat menyusun huruf-huruf dalam kata yang sesuai dengan kosakata, dan siswa dapat menterjemahkan 
kata bahasa Inggris ke dalam bahasa Indonesia tentang alat-alat tulis.

Pembelajaran bahasa Inggris di Sekolah dasar meliputi empat keterampilan berbahasa, yaitu mendengarkan, berbicara, membaca, dan menulis (listening, speaking, reading, and writing) dalam konteks sederhana (Kasihani \& Suyanto, 2015:6). Dari keempat keterampilan tersebut, tenyata hasil belajar bahasa Inggris pada siswa kelas IA MI Nurul Anwar Kota Bekasi masih rendah. Anak-anak belum mampu membaca dan berbicara walaupun dengan kosakata yang sangat sederhana. Faktor dari luar siswa yang dapat mempengaruhi prestasi belajar Bahasa Inggris adalah lingkungan belajar siswa baik yang bersifat fisik maupun sosial termasuk di dalamnya yaitu lingkungan keluarga, lingkungan masyarakat, lingkungan alam, lingkungan sekolah dan rendahnya kemampuan membaca dan berbicara pada siswa kelas IA MI Nurul Anwar Kota Bekasi disebabkan karena pendekatan pembelajaran yang kurang menarik serta penyampaiannya yang kurang kreatif dalam pembelajaran bahasa Inggris pada siswa kelas IA.

Melalui metode bernyanyi, diharapkan siswa mampu meningkatkan pengucapan kosakata-kosakata dengan baik dan benar. Dengan menggunakan lagu-lagu yang familiar dengan siswa guru mengubah syair lagu dengan kosakata Bahasa Inggris sesuai materi. Melalui metode ini siswa akan senang sekaligus cepat mudah menghafal kosakata-kosakata bahasa Inggris dan tidak membuat siswa jenuh apalagi merasa takut dan terbebani dengan mata pelajaran bahasa Inggris. Melalui penggunaan metode ini peserta didik diharapkan mampu menguasai kosakata dengan baik dan mampu menerapkanya dalam percakapan-percakapan sederhana hingga kompleks.
Atas dasar itu, peneliti tertarik untuk mengetahui seberapa besar efektivitas metode bernyanyi dalam meningkatkan hasil belajar Bahasa Inggris pada siswa kelas IA. Untuk itu peneliti menjadikan MI Nurul Anwar Kota Bekasi sebagai tempat penelitian, karena masih banyak siswa yang pengetahuannya masih rendah dalam pelajaran Bahasa Inggris. Ketidakmampuan siswa dalam menerima mata pelajara bahas Inggris. Adapun metode dan media yang digunakan masih rendah dan kurang efektif.

Bahwa dengan menggunakan metode bernyanyi penulis berharap dapat meningkatkan hasil belajar kosakata Bahasa Inggris pada siswa kelas IA MI Nurul Anwar Kota Bekasi. Begitu pula dapat mengetahui bahwa dengan menggunakan metode beryanyi dapat meningkatkan minat siswa dalam mengikuti pembelajaran kosakata bahasa Inggris kelas IA MI Nurul Anwar Kota Bekasi.

\section{METODE}

Metode yang digunakan dalam penelitian ini adalah jenis Penelitian Tindakan Kelas (Classroom Action Research). Mulyasa (2012:10) berpendapat penelitian tindakan kelas dapat diartikan sebagai penelitian tindakan (action reserch) yang dilakukan dengan tujuan untuk memperbaiki kualitas proses dan hasil belajar sekelompok peserta didik. Sedangkan menurut Samuel dan Ricky (2013: 9), penelitian tindakan kelas adalah sebuah bentuk penelitian yang bersifflektif, dengan teknik participant observation supaya dapat memperbaiki dan meningkatkan praktik-praktik pembelajaran dalam kelas secara profesional. Menurut pendapat tersebut, penelitian tindakan kelas merupakan suatu pencermatan terhadap kegiatan yang terjadi di dalam kelas.

Menurut Arikunto dkk dalam buku penelitian tindakan kelas (2008:104) mengatakan bahwa penelitian tindakan kelas merupakan suatu bentuk investigasi yang bersifat reflektif partisipasipasif, 
kolaboratif dan spiral, yang memiliki tujuan untuk melakukan perbaikan sistem, metode kerja, proses, isi, kompetensi, dan situasi. Pendapat tersebut sejalan dengan pendapat M.C.Niff beliau memandang penelitian tindakan kelas sebagai bentuk penelitian reflektif yang dilakukan oleh pendidik sendiri terhadap kurikulum, pengembangan sekolah, meningkatkan prestasi belajar, pengembangan keahlian mengajar, dan sebagainya. Berdasarkan pendapat tersebut, bahwa penelitian tindakan kelas merupakan penelitian yang digunakan untukk membantu mengatasi persoalan yang ada di sekolah, untuk meningkatkan prestasi belajar siswa serta untuk mencapai tujuan kerja sama yang telah disepakati secara bersama.

Penelitian ini dilakukan dengan cara melakukan berbagai tindakan untuk meningkatkan kualitas peran dan memecahkan berbagai permasalahan khususnya dalam pengelolaan pembelajaran dikelas. Setiap langkah penelitian ini memilki empat tahap, yaitu membuat perencanaan, membuattindakan, melakukan pengamatan, dan melakukan refleksi. Setelah diketahui masalahnya, kemudian masalah itu diteliti dan dicari bagaimana penyelesaiannya yang pada akhirnya penyelesaian masalah tersebut dapat meningkatkan dan memperbaiki hasil belajar siswa yang selama ini dilaksanakan agar menjadi lebih baik. Dalam penelitian ini diupayakan untuk meningkatkan Hasil belajar Kosakata Bahasa Inggris pada siswa kelas IA MI Nurul Anwar Kota Bekasi.

Dapam penelitian ini, peneliti menggunakan metode penelitian tindakan kelas (classroom action research). Terkait dengan desain penelitian tindakan kelas, penelitian ini menggunakan desain tindakan model Kemmis \& Mc Taggart yaitu siklus terdiri dari empat tahapan yakni, perencanaan (planning), tindakan (acting), observasi (observing), dan refleksi (reflecting) (Suharsmi Arikunto 2008: 16). Desain siklus tindakan dalam penelitian ini terdiri atas beberapa siklus. Setiap siklus dilaksanakan sesuai perubahan yang ingin dicapai.
HASIL DAN PEMBAHASAN

\section{A. Deskripsi Data Hasil Tindakan Prapenelitian}

Penelitian tindakan kelas ini dilaksanakan pada kelas I A MI Nurul Anwar Kota Bekasi dengan 2 (dua) siklus sebanyak 4 kali pertemuan pada setiap siklusnya. Sebelum peneliti melaksanakan tindakan pada siklus I, peneliti melakukan persiapan prapenelitian yaitu mencari dan mengumpulkan data siswa yang akan menjadi subjek penelitian melalui observasi langsung, diskusi dengan guru mata pelajaran Bahasa Inggris, dan memberikan tes prapenelitian kepada siswa dalam satu kali pertemuan.

Berdasarkan hasil observasi dalam pembelajaran bahasa Inggris ada beberapa siswa yang memiliki keterampilan Bahasa Inggris yang bagus. Beberapa siswa tersebut dapat mengucapkan kosakata Bahasa Inggris tersebut dengan pelafalan yang benar, siswa cenderung mau aktif, hasil pembelajaran Bahasa Inggris siswa juga cukup baik, hanya saja sebagian siswa lain belum . sebagian besar siswa selama proses pembelajarn Bahasa Inggris banyak yang tidak mau aktif, bahkan dalam menyelesaikan soal dari guru harus dipaksa dan dibantu gurunya. Berdasarkan hasil wawancara peneliti dengan guru mata mata pelajaran bahasa Inggris. Diketahui bahwa guru kurang memiliki waktu pembelajaran, pertemuan yang hanya seminggu satu kali sebenarnya tidak cukup, padahal materi yang harus dikuasai siswa sangat banyak. Keadaan ini memaksa guru fokus pada menyelesaikan materi dalam waktu yang cepat sehingga tidak bisa memaksimalkan keterampilan siswa.

Satu materi kadang harus dibahas dalam satu kali pertemuan, padahal muatan materi tersebut cukup banyak. Beban materi yang sangat banyak tidak bisa diimbangi siswa, apalagi proses pembelajaran juga berjalan dengan cara itu-itu saja, beberapa siswa yang memiliki daya serap tinggi bisa mengikuti, hanya saja lebih banyak siswa yang memiliki daya serap rata-rata dan sulit mengikuti. Berdasarkan hasil tes 
prapenelitian diketahui bahwa masih banyak siswa yang belum mampu menguasai kosakata bahasa inggris dalam keterampilan mendengarkan, berbicara, membaca, dan menulis. Adapun hasil kemampuan awal siswa kelas I A MI Nurul Anwar Kota Bekasi terlihat dalam tabel dengan menggunakan rumus.

$$
\mathrm{P}=\frac{\sum x}{N} \cdot 100 \%
$$

Keterangan :

$\mathrm{P} \quad=$ Prosentase

$\sum x=$ Nilai yang diperoleh

$N=$ Skor tertinggi yang diperoleh

Adapun hasil nilai rata-rata(mean) dari seluruh siswa dalam satu kelas.

$$
\mathrm{Me}=\sum \frac{x i}{n}
$$

Keterangan :

$\mathrm{Me}=$ rata-rata (mean)

$\Sigma \quad=$ episolen (baca jumlah)

$x i \quad=$ nilai $x$ ke $\mathrm{i}$ sampai $\mathrm{n}$

$\mathrm{N}=$ Jumlah siswa

\section{Table 1 Hasil Data Prapenelitian}

\begin{tabular}{|r|l|l|l|}
\hline Total Nilai & 671 & 1.220 & $\begin{array}{l}\text { Belum } \\
\text { tercapai } \\
100 \%\end{array}$ \\
\hline Rata-rata & 33,89 & 33,89 & \\
\hline
\end{tabular}

Berdasarkan analisis kuantitatif tersebut di atas, dapat disimpulkan bahwa hasil belajar kosakata Bahasa Inggris siswa belum dapat dikatakan memenuhi standar KKM yaitu $75 \%$. Oleh karena itu, peneliti merencanakan kegiatan tindakan kelas pada pembelajaran yang direncanakan pada siklus I dengan memakai desain perencanaan, pelaksanaan, pengamatan dan refleksi.

Jika dilihat melalui grafik, maka dapat diketahui sejauh mana hasil belajar kosakata Bahasa Inggris siswa sebelum dilakukan tindakan. Berikut ini, peneliti sajikan data pra penelitian dalam bentuk grafik.

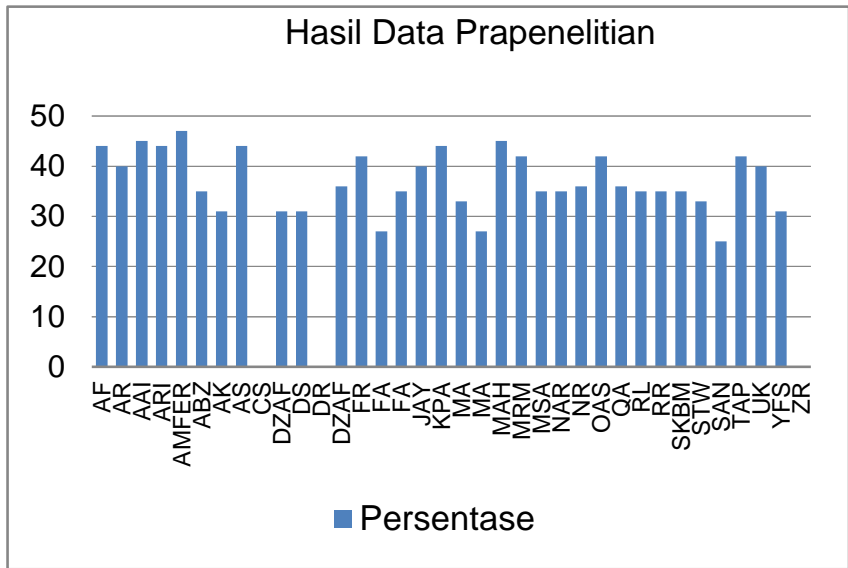

\section{Gambar 1 Grafik Hasil Pra Penelitian}

Dari hasil perhitungan data pra penelitian di atas, maka telah nampak bahwa perolehan nilai tersebut menunjukkan tingkat hasil belajar kosakata Bahasa Inggris siswa kelas I A MI Nurul Anwar Kota Bekasi masih rendah dan kurang dari target yang diharapkan, yaitu nilai KKM 75 dari yang diperoleh masingmasing siswa. Hal ini dapat menjadi dasar untuk dilaksanakannya tindakan bagaimana meningkatkan hasil belajar kosakata Bahasa Inggris siswa kelas I A MI Nurul Anwar Kota Bekasi.

\section{B. Deskripsi Data Hasil Tindakan Siklus I}

Pada siklus I, tindakan yang diberikan dilakukan secara bertahap yaitu selama 4 kali pertemuan. Setiap kali pertemuan berlangsung selama 70 menit atau dua jam mata pelajaran. Adapun peran peneliti dalam penelitian ini adalah sebagai pemberi tindakan dan sebagai pengamat. Sehingga peneliti terlibat langsung bersama siswa dalam upaya meningkatkan hasil belajar kosakata Bahasa Inggris melalui metode bernyanyi.

Tindakan ini akan diberikan pada seluruh siswa kelas I A MI Nurul Anwar Kota Bekasi yang berjumlah 36 siswa. Yang terdiri dari 15 laki-laki dan 21 perempuan. Kegiatan pembelajaran yang terkait dengan meningkatkan hasil belajar kosakata Bahasa Inggris ini dikemas secara menarik 
dalam sebuah metode yang menyenangkan yaitu menggunakan nyanyian.

Selama melakukan tindakan, peneliti dan kolaborator mendiskusikan program tindakan yang akan dilakukan. Peneliti bekerja sama dengan kolaborator yang bertugas membantu mengamati selama program tindakan diberikan, serta peneliti juga mempersiapkan lembari nstrumen kegiatan dan evaluasi, serta lembar penilaian dimana lembar penilaian tersebut akan digabungkan dan hasilnya digunakan untuk melihat hasil belajar kosakata Bahasa Inggris melalui metode bernyanyi, serta alat dokumentasi berupa kamera.

Hasil yang didapat dari tahap siklus I yang dianalisis dan dikumpulkan, ternyata hasil yang dicapai belum memenuhi target $\mathrm{KKM}$, sehingga perlu dilanjutkan untuk kemudian ditingkatkan pada siklus berikutnya.

\section{Tabel 2 Hasil Data Siklus I}

\begin{tabular}{|c|c|c|c|}
\hline Total Nilai & 1.158 & 2.105 & \multirow{2}{*}{$\begin{array}{l}\text { Tercapai } 50 \% \text { dari } \\
36 \text { siswa }\end{array}$} \\
\hline Rata-rata & 58,48 & 58,48 & \\
\hline
\end{tabular}

Berdasarkan deskripsi data tindakan pada siklus I, peningkatan hasil belajar kosakata bahasa Inggris siswa MI Nurul Anwar kelas IA setelah diberikan tindakan pada siklus I rata-rata adalah 58,48\% mengalami kenaikan yang baik jika dibandingkan rata-rata kelas pada tes prapenelitian yaitu 33,89\%. Maka didapatkan persentase kenaikan sebesar $24,59 \%$. Berikut peneliti sajikan data penelitian siklus I dalam bentuk grafik.

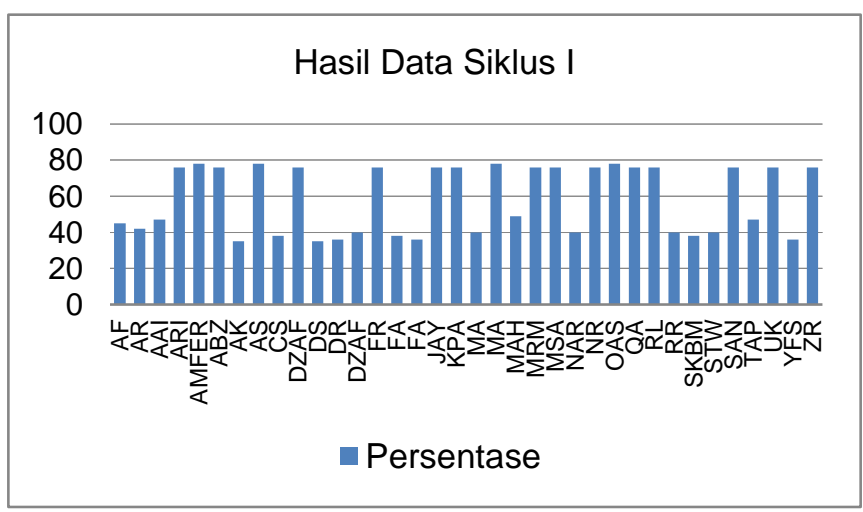

Gambar 2 Grafik Hasil Data Siklus I
Adapun hasil refleksi yang didapat, terdapat kekurangan dan kelalaian yang dilakukan peneliti pada siklus I ini diantaranya, pemanfaatan waktu yang belum maksimal, metode pembelajaran yang belum dilaksanakan dengan baik, mobilitas posisi mengajar yang kurang efektif dan belum maksimal dalam mencontohkan nyanyian. Dikarenakan adanya kekurangan yang peneliti dapatkan pada siklus I, maka peneliti akan memperbaiki tindakan pada siklus selanjutnya. Perencanaan tindakan yang dirancang pada siklus II ini sama seperti pada siklus I, karena merupakan tindak lanjut dari siklus I.

\section{Deskripsi Data Hasil Tindakan Sikus II}

Berdasarkan hasil refleksi pada siklus I dan permasalahan yang ditemukan, terdapat 18 siswa yang sudah mengalami peningkatan sesuai KKM yang telah ditentukan yaitu 75. Dan tersisa 18 siswa yang belum mencapai KKM. Siswa yang sudah mencapai nilai KKM pada siklus I, peningkatan hasil belajar kosakata bahasa Inggris melalui metode bernyanyi, diteliti lagi oleh peneliti pada siklus II tetapi masih mengikuti kegiatan pembelajaran dan melakukan tes hasil belajar kosakata bahasa Inggris. Pelaksanaan siklus II dilakukan sebanyak 4 kali pertemuan. Hasil yang didapat dari tahap siklus II yang dianalisis dan dikumpulkan, ternyata hasil yang dicapai sudah sesuai dengan target yang ditentukan. Tindakan-tindakan yang dilakukan yaitu dengan menggunakan metode bernyanyi.

Tabel 3 Hasil Data Siklus II

\begin{tabular}{|c|c|c|c|}
\hline $\begin{array}{l}\text { Total } \\
\text { Nilai }\end{array}$ & 1561 & 2.838 & Tercapai $100 \%$ \\
\hline $\begin{array}{l}\text { Rata- } \\
\text { rata }\end{array}$ & 78,83 & 78,83 & dari 36 siswa \\
\hline
\end{tabular}


Berdasarkan tabel tersebut, dapat disimpulkan bahwa dari 36 siswa yang menjadi subjek penelitian, semua siswa telah mencapai ketercapaian yang telah ditentukan dengan total skor 78,83 \% yang semuanya telah memenuhi kriteria ketercapaian untuk peningkatan hasil belajar kosakata Bahasa Inggris melalui metode bernyanyi. Dengan demikian penelitian dengan subjek penelitian sebanyak 36 siswa sudah meningkat dan tercapai sesuai dengan hasil intervensi tindakan yang diharapkan.

Berikut peneliti sajikan data penelitian siklus II dalam bentuk grafik:

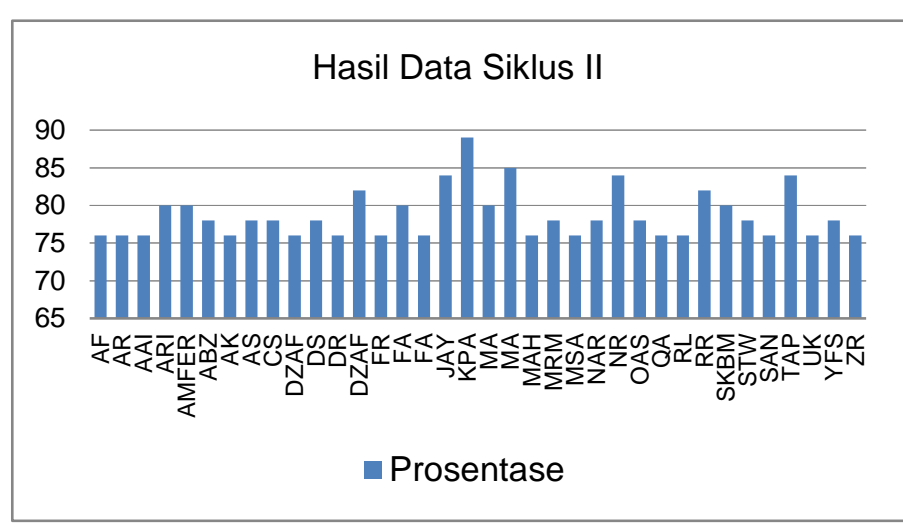

Gambar 3 Grafik Hasil Data Siklus II

Berdasarkan dari data yang diperoleh, hasil belajar kosakata bahasa Inggris pada siswa kelas I A MI Nurul Anwar Kota Bekasi setelah diberi tindakan pada siklus II, rataratanya adalah $78,83 \%$ telah mencapai KKM yang ditentukan yaitu $75 \%$ mengalami peningkatan jika dibandingkan dengan ratarata pada siklus I yaitu 58,48\%. Berdasarkan perbandingan rata-rata siklus I dengan siklus II, maka didapatkan kenaikan persentase sebesar $20,35 \%$.

\section{Hasil Analisis Data}

Berdasarkan hasil penelitian tindakan dapat dinyatakan bahwa terjadi peningkatan hasil belajar kosakata Bahasa Inggris melalui metode bernyanyi dari prapenelitian sampai pada siklus I kemudian pada siklus I sampai pada siklus II. Berikut peneliti sajikan tabel dan grafik kenaikan prosentase.

\section{Tabel 4 Perbandingan Kenaikan Prosentase dari Data Pra penelitian ke Siklus I Sampai Pada Siklus II}

\begin{tabular}{|c|c|}
\hline Prapenelitian & $\mathbf{3 3 , 8 9} \%$ \\
\hline Peningkatan & $\mathbf{2 4 , 5 9} \%$ \\
\hline Siklus I & $\mathbf{5 8 , 4 8} \%$ \\
\hline Peningkatan & $\mathbf{2 0 , 3 5} \%$ \\
\hline Siklus II & $\mathbf{7 8 , 8 3} \%$ \\
\hline
\end{tabular}

Sedangkan dalam bentuk grafik sebagai berikut:

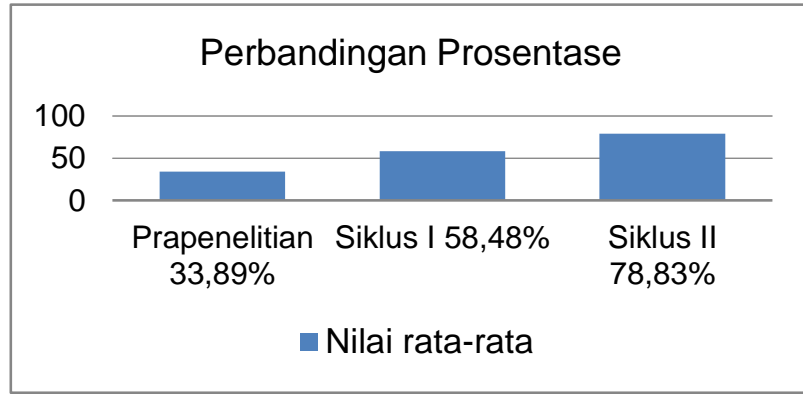

\section{Grafik 4 Perbandingan Kenaikan Prosentase Dari Data Prapenelitian, Siklus I, Sampai pada Siklus II}

Berdasarkan pada table dan grafik di atas, menunjukkan bahwa penerapan metode bernyanyi dalam pembelajaran bahasa Inggris siswa kelas I A MI Nurul Anwar Kota Bekasi dapat menjadio petunjuk dan rangsangan siswa untuk memberikan respon yang diinginkan. Petunjuk dan rangsangan siswa yang ditunjukkan dalam penelitian ini dapat terlihat dari peningkatan hasil belajar kosakata Bahasa Inggris.

Pada observasi awal, guru belum menggunakan metode pembelajaran secara optimal sehingga pembelajaran kosakata bahasa Inggris yang diajarkan guru kurang maksimal. Guru hanya memberikan arti kata secara lisan dan belum memberikan kesempatan kepada siswa untuk membaca kosakata bahasa Inggris yang sedang dipelajari secara mendalam, sehingga ketika dilakukan tes awal jumlah rata-rata nilai siswa $33,89 \%$. Dilihat dari nilai siswa 
setiap aspek juga masih rendah. Oleh karena itu, dalam pembelajaran bahasa Inggris diperlukan tindakan untuk mengatasi masalah yang terjadi dalam hasil belajar kosakata bahasa Inggris.

Pada siklus I peneliti telah menggunakan metode bernyanyi sebagai metode pembelajaran untuk memberi konteks kata dan arti kata yang baru diajarkan pada siswa. Sehingga setiap siswa dapat menyanyikannya dimana pun, setelah digunakan metode bernyanyi, terjadi peningkatan hasil belajar kosakata bahasa Inggris.Setelah dilakukan tes pada akhir siklus I, terlihat bahwa terjadi peningkatan rata-rata siswa $58,48 \%$ dari sebelum dilakukan tindakan $33,89 \%$ terjadi peningkatan sebesar $24,59 \%$. Peneliti ini berlanjut pada siklus II karena pada siklus I belum mencapai kriteria ketuntasan yang ditetapkan yaitu $75 \%$.

Pada siklus II masih menggunakan metode bernyanyi dengan nyanyian yang sama, karena dengan nyanyian yang sama dapat memudahkan siswa dalam proses pembelajaran dan dapat selalu di inggat nyanyian kosakata alat-alat tulis tersebut.

Peningkatan hasil belajar kosakata bahasa Inggris terlihat dari peningkatan jumlah siswa yang mencapai skor maksimal. Pada siklus II semua siswa dapat mencapai nilai KKM yang telah ditentukan. Terlihat bahwa terjadi peningkatan rata-rata nilai siswa yang mencapai $78,83 \%$ dari sebelum tindakan siklus I $58,48 \%$ terjadi peningkatan sebesar $20,35 \%$. Penelitian ini dicukupkan pada siklus II karena telah mencapai kriteria ketuntasan yang ditetapkan yaitu sebesar $100 \%$ dari jumlah siswa yang mencapai 75 . Maka penelitian ini dianggap berhasil

Berdasarkan peningkatan nilai ratarata hasil belajar kosakata Bahasa Inggris dan persentase di atas diketahui bahwa penggunaan metode bernyanyi dapat meningkatkan hasil belajar kosakata bahasa Inggris pada siswa kelas I A MI Nurul Anwar Kota Bekasi.

\section{PENUTUP}

Berdasarkan hasil penelitian yang dilakukan oleh peneliti tentang peningkatan hasil belajar kosakata bahasa Inggris melalui metode bernyanyi pada siswa kelas I MI Nurul Anwar Kota Bekasi. Dapat disimpulkan bahwa terjadi peningkata persentase nilai rata-rata siklus I dan siklus II setelah diketahui hasil tes awal pada tes prapenelitian.

Pada siklus I rata-rata kelas adalah $58,48 \%$, mengalami peningkatan jika dibandingkan dengan nilai rata-rata pada tahap prapenelitian sebesar 33,89\%. Berdasarkan perbandingan rata-rata kelas prapenelitian dengan siklus I, maka didapat prosentase kenaikan sebesar 24,59\%. Untuk melengkapi penyempurnaan data penelitian dan pencapaian standar KKM yang telah ditentukan yaitu $75 \%$, maka peneliti melaksanakan siklus II. Berdasarkan hasil analisis data, pada siklus II terjadi peningkatan hasil rata-rata kelas menjadi $78,83 \%$, mengalami peningkatan bila dibandingkan dengan rata-rata kelas pada siklus I yaitu $58,48 \%$. Berdasarkan perbandingan rata-rata kelas pada siklus I dengan siklus II, maka didapat kenaikan prosentase sebesar $20,35 \%$.

Dapat dinyatakan bahwa penerapan metode bernyanyi dapat meningkatkan hasil Dapat dinyatakan bahwa penerapan metode bernyanyi dapat meningkatkan hasil belajar kosakata bahasa Inggris. Dengan demikian peneliti ini dapat menyimpulkan sebagai berikut :

1. Berdasarkan data catatan lapangan dan lembar tugas siswa yang dilakukan pada setiap siklus pembelajaran, terdapat peningkatan hasil belajar kosakata bahasa Inggris disetiap siklus.

2. Kegiatan pembelajaran kosakata bahasa Inggris dengan menggunakan metode bernyanyi dapat membuat siswa 
untuk lebih termotivasi dan lebih semangat dalam proses pembelajaran

3. Selain pemilihan media dan metode yang tepat, latihan menyelesaikan soal baik secara lisan maupun tulisan yang berkesinambungan juga dapat meningkatkan hasil belajar kosakata bahasa Inggris siswa dalam menjawab soal-soal yang diberikan oleh peneliti. Karena siswa diberikan siswa diberikan waktu yang cukup untuk mempelajari bahan kosakata, sehingga mengurangi kegagalan siswa dalam belajar dan pada akhirnya mendapatkan hasil yang optimal.

4. Metode bernyanyi merupakan sebuah metode yang mudah dipakai. Metode ini hanya memerlukan lagu, dan speaker yang tidak membutuhkan dana

\section{REFERENSI}

Andriyansyah, A. (2019). Penanaman Toleransi Agama Pada Diri Anak Melalui Doktrin Sejarah Kebudayaan Islam (PENELITIAN TINDAKAN KELAS PADA MI HIDAYATUL AHBABINA, SETU, BEKASI). EL BANAR: JURNAL PENDIDIKAN DAN PENGAJARAN, 2(02), 121-126.

Arikunto, Suharsimi, dkk. (2008). Penelitian Tindakan Kelas. Jakarta. Sinar Grafika.

Buasim. (2016). Pendidikan Bahasa Inggris. Tanerang Selatan. Universitas Terbuka

Departemen Agama. (2000). Al-Qur'an dan Terjemahan. Bandung : CV. Diponegoro

Kasihani K.E. Suyanto. (2015). English For Young Learners. Jakarta. Bumi Aksara Mulyasa. (2012). Praktik Penelitian Tindakan Kelas. Bandung. Remaja Rosdakarya

Nurhid. (2016). 45 Model Pembelajaran Spektakuler. Jogjakarta. Ar-Ruzz Media.

Samuel. (2013). Asyiknya Penelitian IImiah dan Penelitian Tindakan Kelas.

Yogyakarta. Andi Offset dikarenakan hampir semua sekolah memiliki speaker untuk keperluan sekolah.

\section{UCAPAN TERIMA KASIH}

Alhamdulillah wa Syukrulillah, penulis panjatkan kehadirat Allah Subhanahu wa ta'ala karena atas rahmat dan pertolonganNya, penulis dapat menyelesaian penelitian ini dengan baik. Tak lupa juga penulis ucapkan terimakasih yang sebesarbesarnya kepada dosen pembimbing dan seluruh civika akademik STAI Bani Saleh Bekasi yang selalu memberikan arahan dan motivasi kepada penulis. Begitu juga kepada seluruh pihak yang telah memberikan bantuan dan dukungan untuk menyelesaikan penelitian ini. 